\title{
Bacillus asahii sp. nov., a novel bacterium isolated from soil with the ability to deodorize the bad smell generated from short-chain fatty acids
}

Correspondence
Isao Yumoto
i.yumoto@aist.go.jp

\author{
Isao Yumoto, ${ }^{1}$ Kikue Hirota, ${ }^{1}$ Shingo Yamaga, ${ }^{1,2}$ Yoshinobu Nodasaka, ${ }^{3}$ \\ Tsuneshirou Kawasaki, ${ }^{4}$ Hidetoshi Matsuyama ${ }^{2}$ and Kenji Nakajima ${ }^{1}$ \\ ${ }^{1}$ Research Institute of Genome-based Biofactory, National Institute of Advanced Industrial \\ Science and Technology (AIST), Tsukisamu-Higashi, Toyohira-ku, Sapporo 062-8517, Japan \\ ${ }^{2}$ Department of Bioscience and Technology, School of Engineering, Hokkaido Tokai University, \\ Minaminosawa, Minami-ku, Sapporo 005-8601, Japan \\ ${ }^{3}$ Laboratory of Electron Microscopy, School of Dentistry, Hokkaido University, Kita-ku, Sapporo \\ 060-8586, Japan \\ ${ }^{4}$ Asahi Vet Japan Co., Ltd, 724-1 Midorimachi, Shiraoi-cho, Hokkaido 059-0931, Japan
}

Recently, offensive smells emanating from faeces in limited spaces where a large number of livestock and poultry are kept have become a serious environmental problem in Japan. The smell is caused by short-chain fatty acids, ammonia, indole and trimethylamine, etc., contained in the animal faeces. The use of micro-organisms with the ability to deodorize animal faeces has been considered as a possible solution to the problem. Strain MA001 ${ }^{\mathrm{T}}$ had been screened and isolated with the aim to remove the bad smell from animal faeces (Aoshima, 1996, 1998a, b). The isolate was able to reduce levels of the compounds causing the bad smell and was tentatively identified as Bacillus badius based only on phenotypic characterization at the time. Therefore, the application of more informative classification procedures had

Published online ahead of print on 23 April 2004 as DOI 10.1099/ ijs.0.03014-0.

The GenBank/EMBL/DDBJ accession number for the 16S rRNA gene sequence of strain $M A 001^{\top}$ is $A B 109209$. been necessary for a more precise identification of the isolate.

In the present study, taxonomic studies were performed on the isolated micro-organism, which exhibits a deodorizing effect on animal faeces. Physiological and biochemical characterization, phylogenetic analysis based on 16S rRNA gene sequences and DNA-DNA hybridization on the isolate and phylogenetic neighbours showed that the isolate should be classified as a novel species belonging to the genus Bacillus.

The strain examined was Bacillus sp. MA001 ${ }^{\mathrm{T}}$ isolated from soil obtained from Tagata-gun, Shizuoka, Japan. The isolate was cultured in PY-1 medium ( $\mathrm{pH} 7.9$ ) containing $8 \mathrm{~g}$ peptone (Kyokuto), 3 g yeast extract (Merck) and $15 \mathrm{~g}$ agar (if required) in 1 litre of distilled water. Cells for chemotaxonomic analysis were harvested in the late-exponential phase after cultivation with reciprocal shaking (140 r.p.m.) in PY-1 broth at $27^{\circ} \mathrm{C}$. In addition to the isolate, Bacillus 
psychrosaccharolyticus ATCC $23296^{\mathrm{T}}$, Bacillus flexus ATCC $49095^{\mathrm{T}}$, Bacillus simplex ATCC $49097^{\mathrm{T}}$ and Bacillus badius IAM $11059^{\mathrm{T}}$ were used as reference for phenotypic characteristics, utilization of butyrate and DNA-DNA hybridization with the isolate. These micro-organisms were cultivated under the same conditions.

For phenotypic characterization, PY- 1 was used as the basal medium. The culture was incubated at $27^{\circ} \mathrm{C}$ for 2 weeks and the phenotypic characterization experiment was performed three times. Acid production from carbohydrates was determined by the method of Hugh \& Leifson (1953). The growth experiment at $\mathrm{pH}$ 5-10 was performed using PY-1 medium containing $100 \mathrm{mM}$ acetate buffer, $100 \mathrm{mM}$ $\mathrm{NaH}_{2} \mathrm{PO}_{4} / \mathrm{Na}_{2} \mathrm{HPO}_{4}$ buffer and $100 \mathrm{mM} \mathrm{NaHCO} / \mathrm{Na}_{2} \mathrm{CO}_{3}$ buffer, at $\mathrm{pH}$ 5, 6-8 and 9-10, respectively. Requirement for and tolerance of $\mathrm{NaCl}$ was determined using a medium ( $\mathrm{pH} 7 \cdot 7)$ containing $2 \mathrm{~g}$ glucose, $1 \mathrm{~g}$ peptone (Difco), $0 \cdot 1 \mathrm{~g}$ yeast extract (Difco) and $0-20 \% \mathrm{NaCl}$ at $1 \%$ intervals in 1 litre of distilled water. Other physiological and biochemical characteristics were examined according to the methods as described in Barrow \& Feltham (1993). Enzymic activity was determined by using API ZYM (bioMérieux).

For observation of negatively stained cells under a transmission electron microscope (TEM) and platinum- and palladium-coated cells under a scanning electron microscope (SEM), cells were grown on a PY-1 agar slant. The procedure for TEM and SEM preparations and observations were performed as described by Yumoto et al. (2002).

Analysis of whole-cell fatty acids was performed as described by Yumoto et al. $(2001,2002)$.

Bacterial DNA was prepared according to the method of Marmur (1961). The DNA base composition was determined by the HPLC method of Tamaoka \& Komagata (1984). The level of DNA-DNA relatedness was determined fluorometrically by the method of Ezaki et al. (1989) using photobiotin-labelled DNA probes and black microplates.

The 16S rRNA gene sequence corresponding to positions 27-1519 in the 16S rRNA gene sequence of Escherichia coli (Brosius et al., 1978) was amplified by PCR. The PCR product (about $1.5 \mathrm{~kb}$ ) was sequenced directly by the dideoxynucleotide chain-termination method using a DNA sequencer (PRISM 377; Applied Biosystems). Multiple alignments of the sequence were performed and the nucleotide substitution rate ( $K_{\text {nuc }}$ value) was calculated. A phylogenetic tree was constructed by the neighbour-joining method (Kimura, 1980; Saitou \& Nei, 1987) using the CLUSTAL W program (Thompson et al., 1994). Similarity values for sequences were calculated using the GENETYX computer program (Software Development).

The isolate grew better $\left(\mathrm{OD}_{650} 0 \cdot 145\right)$ in $0 \cdot 3 \%$ sodium butyrate as short-chain fatty acid supplemented medium containing $0.02 \%$ yeast extract $(\mathrm{pH} 7.9)$ than in the same medium devoid of the short-chain fatty acid control $\left(\mathrm{OD}_{650}\right.$
$0 \cdot 001)$. Utilization of butyrate was also observed in $B$. simplex ATCC $49097^{\mathrm{T}}$, B. flexus ATCC $49095^{\mathrm{T}}$ and B. badius IAM $11059^{\mathrm{T}}$. The $\mathrm{OD}_{650}$ ratio in medium containing sodium butyrate versus control was higher (145) than for other tested strains $(2 \cdot 5-13 \cdot 5)$. Obvious utilization of butyrate was not observed in B. psychrosaccharolyticus ATCC $23296^{\mathrm{T}}$ because of its low growth on the medium used in this experiment. Electron microscopic observations by TEM and SEM of strain MA001 ${ }^{\mathrm{T}}$ revealed peritrichously flagellated rods of $1 \cdot 4-3 \cdot 0 \times 0 \cdot 4-0 \cdot 8 \mu \mathrm{m}$ (Fig. 1).

Physiological and biochemical characteristics of the isolate are given in the species description. The isolate was a Grampositive, spore-forming, rod-shaped aerobic bacterium. These results suggested that this isolate belonged to the genus Bacillus. However, the strain did not produce acid from any carbohydrates tested. These characteristics are quite rare among members of the genus Bacillus (Priest et al., 1988).

GLC analysis revealed that the methyl ester derivatives of fatty acids of the strain mainly consisted of iso- $\mathrm{C}_{15: 0}$ $(39 \cdot 0 \%)$, anteiso- $\mathrm{C}_{15: 0}(27 \cdot 8 \%)$, iso- $\mathrm{C}_{14: 0}(9 \cdot 7 \%)$ and $\mathrm{C}_{16: 1}(5 \cdot 4 \%)$. The fatty acid profile further indicated that the isolate belonged to the genus Bacillus.

The $16 \mathrm{~S}$ rRNA gene DNA of strain MA001 ${ }^{\mathrm{T}}$ was sequenced to determine its phylogenetic position. The 16S rRNA gene $(1504 \mathrm{bp})$ of strain MA001 ${ }^{\mathrm{T}}$ was compared with the sequence of 18 other species belonging to the genus Bacillus as well as other taxa. The phylogenetic tree, constructed using the neighbour-joining method (Fig. 2), and the 16S rRNA gene similarity values (data not shown) indicated that strain MA001 ${ }^{\mathrm{T}}$ was phylogenetically related to other members of the family Bacillaceae. Strain MA001 ${ }^{\mathrm{T}}$ was placed in the group 1 Bacillaceae (Ash et al., 1991) in this phylogenetic tree. The highest sequence similarity value was observed

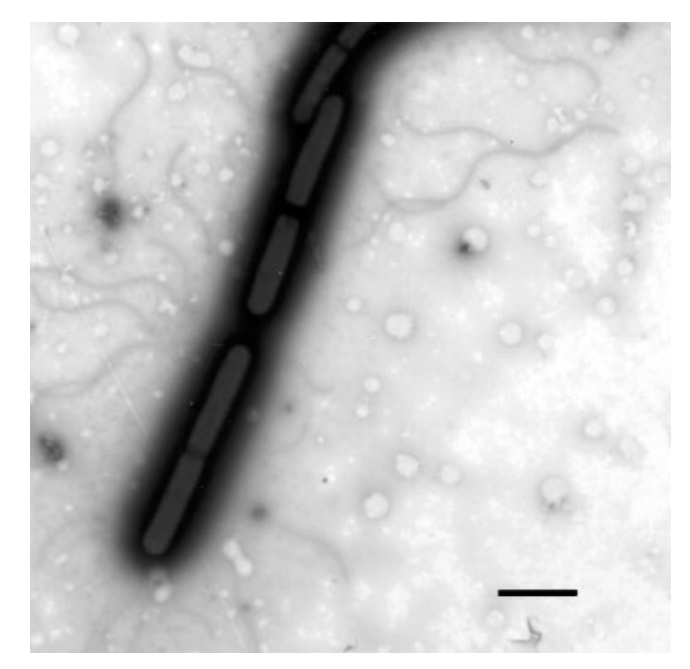

Fig. 1. Negatively stained cell of Bacillus asahii $\mathrm{MAOO1}^{\top}$, showing peritrichous flagellation. Bar, $2 \mu \mathrm{m}$. 


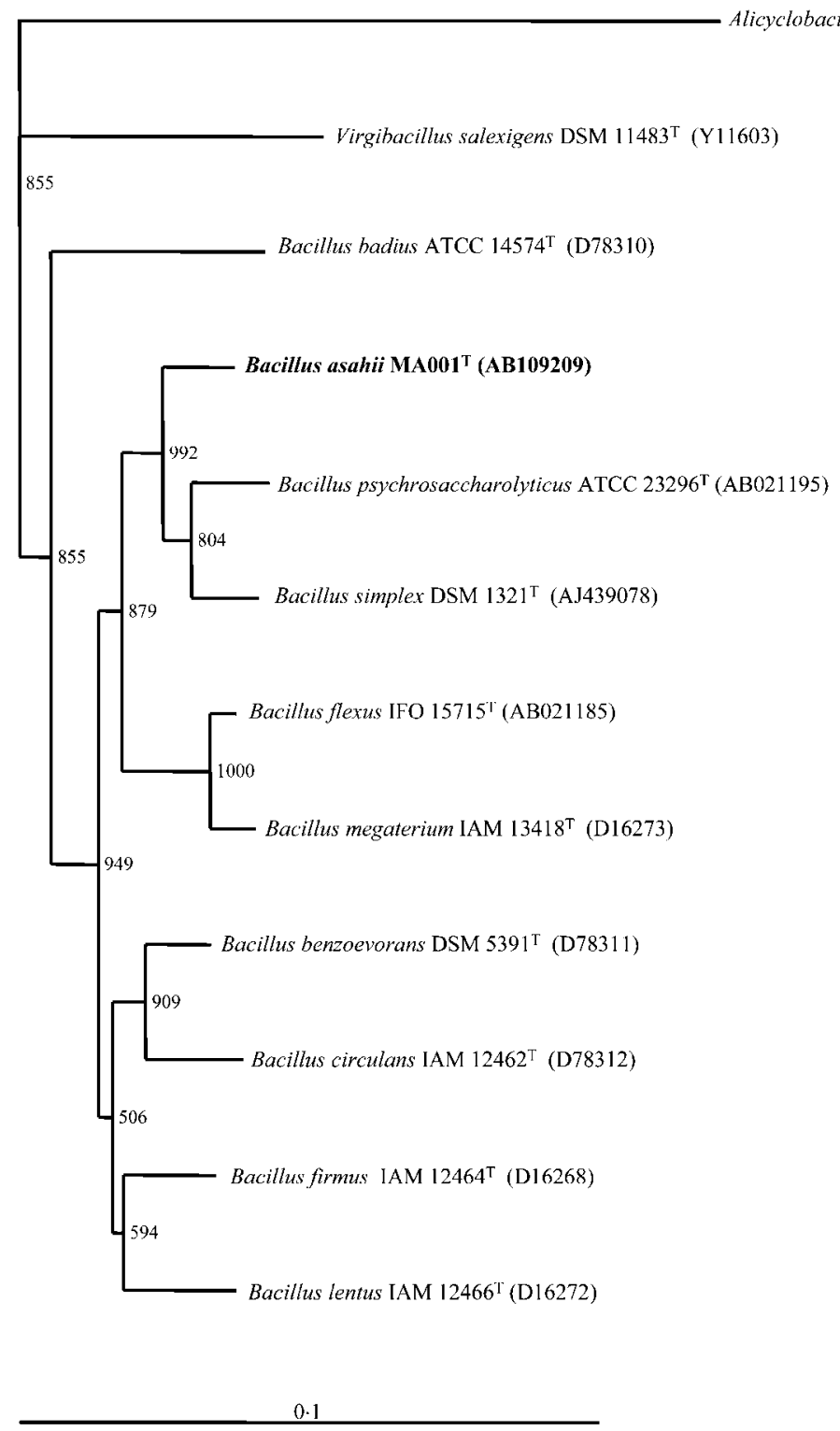

Fig. 2. Phylogenetic tree derived from $16 \mathrm{~S}$ rRNA gene sequence data of Bacillus asahii, members of other Bacillus species and other taxa using the neighbour-joining method. Numbers indicate bootstrap values greater than 500. Bar, $0.01 K_{\text {nuc }}$ unit.

with B. simplex (GenBank/EMBL/DDBJ no. AJ439078) $(97 \cdot 2 \%)$ and B. psychrosaccharolyticus (GenBank/EMBL/ DDBJ no. AB021195) (95.9\%).

The DNA G $+\mathrm{C}$ content of strain $\mathrm{MA001}{ }^{\mathrm{T}}$ was $39 \cdot 4 \mathrm{~mol} \%$, which is within the definition range of the genus Bacillus. DNA-DNA relatedness was estimated using B. simplex ATCC $49097^{\mathrm{T}}$ and B. psychrosaccharolyticus ATCC $23296^{\mathrm{T}}$, which were closely related based on $16 \mathrm{~S}$ rRNA gene sequence analysis, and other related strains, B. flexus ATCC $49095^{\mathrm{T}}$ and $B$. badius IAM $11059^{\mathrm{T}}$. DNA-DNA relatedness values between strain $\mathrm{MA001}{ }^{\mathrm{T}}$ and B. simplex ATCC $49097^{\mathrm{T}}$, B. psychrosaccharolyticus ATCC $23296^{\mathrm{T}}$, B. flexus ATCC $49095^{\mathrm{T}}$ and $B$. badius IAM $11059^{\mathrm{T}}$ were $8,3,9$ and $4 \%$ respectively. These values were highly reproducible. Strain MA $001^{\mathrm{T}}$ was thus very different from other tested strains.

Phenotypic characteristics were examined using the same

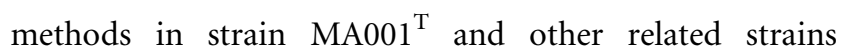
(Table 1). Although these results differ from those reported by Priest et al. (1988) in several regards, they were reproducible. Strain MA001 ${ }^{\mathrm{T}}$ can be differentiated from other relatively closely related species based on its phenotypic characteristics. Although strain MA001 ${ }^{\mathrm{T}}$ was very similar to B. badius IAM $11059^{\mathrm{T}}$, it was differentiated based on several phenotypic characteristics.

On the basis of the above results, we conclude that the isolate should be classified as representing a novel species, for which the name Bacillus asahii sp. nov. is proposed.

\section{Description of Bacillus asahii sp. nov.}

Bacillus asahii (as.a.hi'i. N.L. gen. n. asahii of Asahi; named after Asahi Kasei Co. A researcher working in the company isolated the bacterium). 
Table 1. Phenotypic characteristics of Bacillus asahii sp. nov. and related species

Strains: 1, B. asahii; 2, B. psychrosaccharolyticus; 3, B. simplex; 4, B. flexus; 5, B. badius. All strains are positive for growth at $15{ }^{\circ} \mathrm{C}$, esterase/lipase (C8) and leucine arylamidase. All are negative for acid produced from arabinose and growth in $5 \% \mathrm{NaCl}$. +, Positive; -, negative; w, weakly positive.

\begin{tabular}{|c|c|c|c|c|c|}
\hline Characteristic & 1 & 2 & 3 & 4 & 5 \\
\hline Colony colour & White & White & White & Cream-white & Cream-white \\
\hline Hydrolysis of gelatin & - & - & - & - & + \\
\hline Growth on MacConkey agar & - & + & + & - & + \\
\hline Nitrate reduction & $\mathrm{w}$ & + & + & - & - \\
\hline \multicolumn{6}{|l|}{ Growth at: } \\
\hline $10{ }^{\circ} \mathrm{C}$ & - & + & + & - & - \\
\hline $50^{\circ} \mathrm{C}$ & - & - & - & - & + \\
\hline \multicolumn{6}{|l|}{ Acid produced from: } \\
\hline Xylose & - & + & + & - & - \\
\hline Glucose & - & + & + & + & - \\
\hline Fructose & - & + & - & + & - \\
\hline Mannose & - & + & + & - & - \\
\hline Galactose & - & + & - & + & - \\
\hline Maltose & - & + & + & + & - \\
\hline Sucrose & - & - & - & + & - \\
\hline Lactose & - & + & - & + & - \\
\hline Trehalose & - & + & + & + & - \\
\hline Raffinose & - & - & - & + & - \\
\hline Glycerol & - & + & + & + & - \\
\hline Mannitol & - & + & + & + & - \\
\hline Sorbitol & - & - & + & - & - \\
\hline Growth in $2 \% \mathrm{NaCl}$ & - & - & - & + & - \\
\hline \multicolumn{6}{|l|}{ Enzymic reaction: } \\
\hline Alkaline phosphatase & - & + & + & + & + \\
\hline Valine arylamidase & - & - & - & + & - \\
\hline Cystine arylamidase & - & - & - & + & - \\
\hline Trypsin & + & + & - & - & + \\
\hline Chymotrypsin & - & + & + & + & - \\
\hline Acid phosphatase & - & - & + & + & - \\
\hline$\beta$-Galactosidase & - & + & - & + & - \\
\hline$\alpha$-Glucosidase & - & + & + & + & - \\
\hline$\beta$-Glucosidase & - & + & - & - & - \\
\hline$N$-Acetyl- $\beta$-glucosaminidase & - & + & - & - & - \\
\hline
\end{tabular}

Cells are Gram-positive peritrichously flagellated straight rods $(1 \cdot 4-3 \cdot 0 \times 0 \cdot 4-0 \cdot 8 \mu \mathrm{m})$ and produce terminally or centrally located ellipsoidal spores. Utilizes butyrate as carbon source for growth. Spores do not cause swelling of sporangium. Colonies are circular and white. Catalase and oxidase reactions are positive. Nitrate reduction to nitrite is weakly positive. Negative for indole production, Voges-Proskauer test, methyl red test, growth on MacConkey agar and $\mathrm{H}_{2} \mathrm{~S}$ production. Trypsin, esterase (C4) and esterase/lipase (C8) are positive. Alkaline phosphatase, valine arylamidase, cystine arylamidase, chymotrypsin, acid phosphatase, $\beta$-galactosidase, $\alpha$-glucosidase, $\beta$-glucosidase and $N$-acetyl- $\beta$-glucosaminidase are negative. Growth occurs at pH 6-9; growth at $\mathrm{pH} 5$ is variable.
Growth occurs at $0-1 \% \mathrm{NaCl}$ but not at $\geqslant 2 \% \mathrm{NaCl}$. Growth occurs at $15-45^{\circ} \mathrm{C}$, but not above $50{ }^{\circ} \mathrm{C}$. No acid is produced from D-arabinose, D-xylose, L-rhamnose, Dglucose, D-fructose, D-mannose, D-galactose, maltose, sucrose, lactose, trehalose, cellobiose, melibiose, raffinose, glycerol, mannitol, myo-inositol or sorbitol. Hydrolysis of casein, DNA, and Tweens 20, 40 and 60 is observed but hydrolysis of gelatin is not. Hydrolysis of starch is weakly observed. iso- $\mathrm{C}_{15: 0}(39 \cdot 0 \%)$ and anteiso- $\mathrm{C}_{15: 0}(27 \cdot 8 \%)$ represent the main fatty acids produced during growth in PY-1 medium. The DNA G $+\mathrm{C}$ content is $39 \cdot 4 \mathrm{~mol} \%$, as determined by HPLC.

The type strain, $\quad$ MA001 $1^{\mathrm{T}} \quad\left(=\mathrm{JCM} \quad 12112^{\mathrm{T}}=\mathrm{NCIMB}\right.$ 
$13969^{\mathrm{T}}$ ), was isolated from a soil sample obtained from Tagata-gun, Shizuoka, Japan.

\section{References}

Aoshima, M. (1996). Microorganism and deodorant containing cells thereof. European Patent Application EP 0732391 Al.

Aoshima, M. (1998a). Biologically pure Bacillus badius FERM BP4493 having deodorizing activity. US Patent 5,811,287.

Aoshima, M. (1998b). Microorganism and deodorant containing cells thereof. Kokai Tokkyo Koho 2810308.

Ash, C., Farrow, J. A. E., Wallbanks, S. \& Collins, M. D. (1991). Phylogenetic heterogeneity of the genus Bacillus revealed by comparative analysis of small-subunit-ribosomal RNA sequences. Lett Appl Microbiol 13, 202-206.

Barrow, G. I. \& Feltham, R. K. A. (editors) (1993). Cowan and Steel's Manual for the Identification of Medical Bacteria, 3rd edn. Cambridge: Cambridge University Press.

Brosius, J., Palmer, M. L., Kennedy, P. J. \& Noller, H. F. (1978). Complete nucleotide sequence of a $16 \mathrm{~S}$ ribosomal RNA gene from Escherichia coli. Proc Natl Acad Sci U S A 75, 4801-4805.

Ezaki, T., Hashimoto, Y. \& Yabuuchi, E. (1989). Fluorometric deoxyribonucleic acid-deoxyribonucleic acid hybridization in microdilution wells as an alternative to membrane filter hybridization in which radioisotopes are used to determine genetic relatedness among bacterial strains. Int J Syst Bacteriol 39, 224-229.
Hugh, R. \& Leifson, E. (1953). The taxonomic significance of fermentative versus oxidative metabolism of carbohydrates by various gram negative bacteria. J Bacteriol 66, 24-26.

Kimura, M. (1980). A simple method for estimating evolutionary rates of base substitutions through comparative studies of nucleotide sequences. J Mol Evol 16, 111-120.

Marmur, J. (1961). A procedure for the isolation of deoxyribonucleic acid from microorganisms. J Mol Biol 3, 208-218.

Priest, F. G., Goodfellow, M. \& Todd, C. (1988). A numerical classification of the genus Bacillus. J Gen Microbiol 134, 1847-1882.

Saitou, N. \& Nei, M. (1987). The neighbor-joining method: a new method for reconstructing phylogenetic trees. Mol Biol Evol 4, 406-425.

Tamaoka, J. \& Komagata, K. (1984). Determination of DNA base composition by reversed-phase high-performance liquid chromatography. FEMS Microbiol Lett 25, 125-128.

Thompson, J. D., Higgins, D. G. \& Gibson, T. J. (1994). CLUSTAL W: improving the sensitivity of progressive multiple sequence alignment through sequence weighting, position-specific gap penalties and weight matrix choice. Nucleic Acids Res 22, 4673-4680.

Yumoto, I., Yamazaki, K., Hishinuma, M., Nodasaka, Y., Suemori, A., Nakajima, K., Inoue, N. \& Kawasaki, K. (2001). Pseudomonas alcaliphila sp. nov., a novel facultatively psychrophilic alkaliphile isolated from seawater. Int J Syst Evol Microbiol 51, 349-355.

Yumoto, I., Nakamura, A., Iwata, H., Kojima, K., Kusumoto, K., Nodasaka, Y. \& Matsuyama, H. (2002). Dietzia psychralcaliphila sp. nov., a novel, facultatively psychrophilic alkaliphile that grows on hydrocarbons. Int J Syst Evol Microbiol 52, 85-90. 